\title{
Out of bounds, still in control: exclusion, religious individuation and individualisation during the later Middle Ages
}

Medievalists during the last decades have been well aware of phenomena associated with the process of individualisation, and they have also been aware of different aspects of exclusion, religious exclusion being one of them. Various researchers have taken both issues into account and pointed out how they affected religious discourses and agents in a mutually reinforcing way. However, a wide range of terms is used to describe these phenomena within the historiographical tradition, while one and the same term may be used to denote a number of different concepts, depending, for example, on the distinct field of study to which it is applied. In order to reduce this complexity, the present paper will focus only on a limited time period (namely the later middle ages from the 12th century onward), on the western church (without paying attention to heresy, which has its own history of exclusion) and, with regard to the case studies, mainly on sources from regions within what is now Germany. In order to further clarify the conceptual and terminological difficulties, it is necessary to approach different concepts of individualisation or of the individual as such, and their relations to exclusion, by systemising different accounts. In effect, this means bringing together at least four different approaches, three of them situated within historical research and one within sociological research. I will argue that it is crucial to distinguish forms of voluntary exclusion from forms of non-voluntary exclusion. However, it will also be necessary to take into account the fact that, as far as the impact on individualisation and individuation is concerned, some of these threads may come together in medieval religious discourses and practices when we examine the source material.

\section{How to talk about religious individualisation and individuation with regard to the Middle Ages?}

Historical research over the last few years has dealt with the individual, with the person and the self as well as with private and personal spheres in contrast to 
public and representative spheres on a broad scale. ${ }^{1}$ One of the main topics of research in this context is religion, in particular monastic life and devotional practices. The variety of terms used by scholars is a consequence of a methodological difficulty. Modern theoretical concepts and their related terminology differ from medieval concepts and their terminology (Iogna-Prat 2005b, especially 8f., Goetz 2016, $470 \mathrm{ff}$.). At the same time, we need to take into account the fact that words similar to those used in modern research (e.g. individuum, persona, subiectus) may denote quite different, or at least variant, concepts in medieval sources (Iogna-Prat 2005b, 26-9). This may appear trivial, but it is crucial to decide whether to focus on medieval terminology or to use modern terminology to explore medieval concepts, structures, and practices ('heuristic anachronism', Moos 2006, 253). This is especially important when dealing with exclusion, for some phenomena we now group under this keyword were expressed within the semantic field of inclusion in medieval Latin (Röckelein 2014, 129). Therefore, regarding the topic of this chapter, the relation between exclusion and processes of individualisation or at least individuation, ${ }^{2}$ and its place in the section of this publication concerned with 'Walking the edges', the latter option - to use modern terminology - seems preferable. At the same time, we have to keep in mind that what can be interpreted as exclusion in a modern sense is likely to bear different connotations in medieval source material. It is, thus, necessary to clarify some historiographical principles from which my examination will begin.

Jacob Burckhardt's dictum that the individual was invented only during the Renaissance, whereas people in former times associated themselves exclusively with broad categories, such as corporations and kin, sometimes seems to still echo through the discourse about individuality and concepts of the individual, even though by now many studies have indicated the opposite, or at least called for a differentiated approach. ${ }^{3}$ For example, Jan A. Aertsen makes a plea for methodo-

1 For example, the contributions to a recent conference on one of these topics, the person in the Middle Ages, dealt with a great number of issues (Die Person im Mittelalter: Formen, Zeichen, Prozesse, Frühjahrstagung des Konstanzer Arbeitskreises für mittelalterliche Geschichte e.V. Reichenau, 14th to 17th March 2017), such as death and dying, and law and ecclesiology. For an outline of research positions up to the middle of the 1990s, see Aertsen 1996. On the basis of previous research, Derschka distinguishes different 'domains of individuality': religion, monasticism, philosophy, law, literature, art, emotions, social relationships, material culture, money, and theories of personality (Derschka 2014, 29-192).

2 Musschenga defines '[...] individualisation as an objective process of social change, individuation as development of personal identity [...]' (Musschenga 2001, 5).

3 For a survey and evaluation of research since Burckhardt's times, see Iogna-Prat 2005b, 8-23. The latest monograph dedicated to the subject of the individual in the Middle Ages deals instead with the High Middle Ages (Derschka 2014). Concerning Burkhardt's dictum and its 
logical and terminological precision. He warns against diffusing concepts of the individual and of personality and against diffusing modern concepts with medieval understandings of individuum and persona. At the same time, he points out that modern notions of individuality and personality are to a great extent based on medieval theological reflection. ${ }^{4}$ It is hardly surprising then that research has frequently taken into consideration works of theology, similar philosophical approaches, and the personal statements of intellectuals (most frequently those from the 12th century onwards). ${ }^{5}$ As Franz-Josef Arlinghaus states, in this field of study sources with an emphasis on introspection and self-reflection that contain hints for distancing oneself from the others serve as markers for measuring gradual stages of individuality (Arlinghaus 2015, 13).

Moreover, modern concepts of the individual, the self, individuation, and individualisation serve as tools to evaluate and to explore medieval societies and political thinking. ${ }^{6}$ Otto Gerhard Oexle for example, referring to Simmels concept of social circles, assumes that medieval group culture (e.g. guilds and fraternities) could serve as a 'benchmark for individuality within a society' (Oexle 2001, 20 with reference to Simmel 1968, 27, 30).

Those groups based on coniuratio could be interpreted as indicators and a factor of a medieval culture of the individual', inasmuch as groups were grounded on the actions of single persons (Oexle 2001, 34). Concerning political thinking and the political mentality, individuality and concepts of personality have been identified in, for example, the time of Henry IV (1050-1106), the excommunicated and deposed king being in conflict with a vast number of princes, lords, bishops, and subjects. According to Tilman Struve, descriptions of individuals became increasingly common motives within historiography during Henry's regency, and individual and personal features became ever more important in these descriptions. Struve assumes that chroniclers then pictured 'the individual yearning for freedom, bursting the bounds of traditional ties' (Struve 2006, 13). From a different perspective, Sverre Bagge traces tendencies 'towards an emphasis on "the inner man” within historiography. In his eyes, Henry's biography, composed

consequences, see ibid., 9-28. While Derschka concentrates - like others in recent times - on the 12th century, Hans-Werner Goetz has emphasised that the phenomena under examination can be found in early medieval times as well, see Goetz 2016, $267 \mathrm{ff}$.

4 Aertsen 1996, IX-XV. See also Iogna-Prat 2005a, 247-70 with regard to ecclesiology and Signori 2005, 119ff. with emphasis on Christianity.

5 For example, most contributions in Aertsen and Speer 1996: Individuum und Individualität im Mittelalter explore concepts of the individuum and individuation in theological and philosophical treatises, although two sections are dedicated to historiography and art.

6 For a thorough consideration of the use of the various terms connected to individualisation in the research history of the field of medieval studies, see Schmitt 2001, 241-9. 
by an anonymous author familiar with the king, can be seen as a pioneer work leading towards the 12th century when subject-related descriptions became popular (Bagge 2002, 308 and 363). Philippe Buc, however, has designated the late 11th century as a period of political individualisation: because a 'transpersonal concept of the state' was established, Henry's contemporaries were able to accuse him of putting his 'private interests' above the interests of the Empire (Buc 2010 61-94). We can see that research here focuses on social structures and norms and on how individuals reacted to them in either a deviant or a productive way, as well as on modes of describing historical actors in narrative sources.

During the last years, Niklas Luhmann's approaches in particular have been a subject of discussion in medieval studies. Luhmann's concept of medieval societies as stratified societies is highly controversial among medievalists. Nevertheless, his views on exclusion and inclusion have stimulated debates about medieval social history. According to Luhmann, inclusion in stratified societies is achieved by identification, by being part of a certain estate ('Stand') or group that is defined by exclusion and inclusion. Individuality could therefore be achieved by allocating a social status (Luhmann 1995, 243f. Cf. Bohn 2006a, 145f.; Bohn 2006b, 35f.). By contrast, in societies shaped by social differentiation the individual is characterised via exclusion, i.e., every single person is forced to establish a reliable role management with regard to several functional systems (science, politics, economics etc.), and being an individual (or a system of its own) is only possible beyond those functional systems (Luhmann 1989, 158f. Cf. Bohn and Hahn 2002, 9, 13; Bohn 2006a, 148ff.; Bohn 2006b, 31ff.). While some studies that start from this approach will be discussed below in the context of the relationship between individualisation/individuation and exclusion, it is worth noting that Peter von Moos has pointed out the need to invert Luhmann's approach when dealing with the status of individuals within medieval canon law (Moos 2005, 271-88). In addition, the authors of a recently published volume (Arlinghaus 2015b) use Luhmann's concept to fathom modes for discussing the self, self-reflection, and introspection in premodern times by distinguishing self- and hetero-referential practices of self-construction. Therefore, modes of autobiographical attempts to inscribe the self into society are used to explore premodern 'individuality' (for a description of this methodological approach, see Arlinghaus 2015a). This volume serves as an example of the continuing interest in premodern sources that contain statements about the author's 'self' and which are sometimes subsumed under the term 'ego-documents' (on this matter see, for example, Schmolinsky 2012). This concern has its roots in the 1970s and has interested historians focusing on literature, spirituality, and mentality (cf. Schmitt 2001, 249ff.).

In medieval studies, the correlation between individuals and social structures or groups seems to be the main starting-point for consideration while the 
individual's internal relation to God is sometimes taken into account as a third factor. A particular approach might, therefore, investigate contexts in which this correlation and its norms are in transition or contested (cf. Fuchs 2015, 336). At the same time, it might aim to reconstruct levels of (de-)traditionalisation, (de-)standardisation and (de-)privatisation, since privatisation often serves as a marker for individuality, whereas traditionalisation and standardisation seem incompatible with individuality (cf. Struve 2006, 13; Rüpke 2013, 7; Fuchs 2015, 334). For that matter, exclusion and inclusion (and hetero-reference and self-reference respectively) can serve as modes of description on the level of social processes as well as on the level of the analysis of historical texts. With regard to the sources, personal statements of excluded individuals could help to show whether exclusion fostered individuation or individualisation, even though we need to bear in mind that these statements may not reveal an actual 'inner self' but more likely help to uncover 'the narratives that would create and shape an institution called individuality' (Arlinghaus 2015, 17). When dealing with social processes that might be called individualisation, it is necessary to consider norms of exclusion, too, as they can reveal how much 'individuality' an excluded individual should have at his or her disposal. But let us first explore the way in which current research deals with religious exclusion in the context of individuation and individualisation.

\section{Correlations between exclusion, individualisation and individuation in religious contexts}

Bernd-Christian Otto refers to individualisation with regard to 'standing-out individuals', i.e. individuals who stand out of something (Otto 2017, 40), an idea that might lead one to conclude that exclusion is at the very core of individualisation. But this would be a rather reckless leap, especially when taking into account that - and here again I draw on Otto's considerations - 'discourses of exclusion' may serve the function of 'othering' and thereby lead to the very opposite of individualisation (Otto 2017, 44f.). Moreover, the self can define itself by means of inclusion, by reference to the values and beliefs of the religious community, thereby shaping its own unique identity (Melville 2002, XV). It is, thus, necessary to distinguish carefully between inclusion and exclusion and to take a close look at the correlation between exclusion and inclusion. It should also be noted that the term 'exclusion' can be applied to various phenomena of medieval religious life. Some of these, such as the dichotomy of orthodoxy/heresy are clearly 
connected to 'othering' but others are connected instead to the configuration of the individual's soul and the development of its inner relation towards God. This assumption requires some explanation. I shall start with forms of self-imposed exclusion and withdrawal because 'self-exclusion' - in contrast to involuntary exclusion (cf. Bohn and Hahn 2002, 10f.) - is considered to be one of the main aspects of religious life in religious practice as well as concerning monastic and ascetic life in the Middle Ages.

\subsection{Self-imposed exclusion, seclusion, and withdrawal from common spaces and society}

Three aspects of self-imposed exclusion require attention: 'private piety', monasticism in combination with similar phenomena, and saintliness, aspects that, in the given order, delineate a curve from a minimal to a maximal degree of exclusion that a human being is able to perform.

'Personal piety' or 'private piety' has been a popular topic of research and is still studied by those working on medieval religious practice. It bears a notion of individuation insofar as individual practices are concerned, and it bears a notion of exclusion insofar the individual is regarded as standing outside of, or at least being detached from, a community. There is some disagreement about what 'personal' or 'private' piety actually means. At this point, it is not necessary to develop a precise definition. For the present line of argument, it will be sufficient to explore the notions of several concepts.

From a theological perspective, Bernhard Lang has highlighted apotropaic elements of personal devotional practices, which he defines as manners of acting and speaking that individuals performed in order to express their enduring emotional relationships with a Deity who grants protection and security. In addition, Lang writes of a 'simple piety without reflection', in contrast to a reflexive religiosity based upon certain meditative methods, which he calls '(Virtuosen-)Spiritualität'. In this sense, personal piety for Lang is the basic form of lay religiosity (Lang 2009). Lang seems to be speaking of religious practices performed in a state of temporary (self-)exclusion from established and standardised forms of religiosity.

Although details of his notion of personal/private piety are not discussed in historical research, one comes across implicit references to exclusion in other studies as well. Eva Irblich, for example, argues in her study of prayer books which belonged or were attributed to the Holy Roman Emperors Frederic III (1415-1493), Maximilian I (1459-1519), and Charles V (1500-1558), that one can distinguish between 'individual features', on the one hand, and features attached to these emperors' roles as rulers, on the other. Speaking of exclusion, Irblich's second 
assumption seems to be more important: in contrast to Lang, she does not speak of apotropaic practices when defining personal devotion but deals with a variety of practices that can be attributed to an individual who withdraws from the community of believers to contemplate. The small size of the books, their limited range of texts, unconventional compilations of texts and iconographies, as well as traces of usage and personal entries, all imply, as Irblich suggests, that the books were used in the context of practices of personal piety (Irblich 1988, 11-45).

Irblich's approach is more common in medieval studies than that of Lang. On the level of objects, private or personal piety is addressed by researchers when a book was kept in a private collection, when images were of small size and were not on display in a public space but in domestic surroundings, and when books and images show traces of use. What makes it legitimate to categorise practices and objects of personal or private devotion as personal and private - something belonging to the sphere of individualisation and individuation - is a moment of temporal exclusion or withdrawal from common rooms and practices. Gabriela Signori demonstrates that these practices were not common for lay people alone, as is shown by the evidence from monasteries (Signori 2005, especially 134). Exclusion here is addressed in a very broad and non-specific sense in this context and the topic thus requires further specification, especially with regard to social structures and norms.

From a modern perspective, the key figure of voluntary religious exclusion throughout the Middle Ages is the monk or nun, at least members of those monastic formations and orders that requested enclosure on a large scale. Yet the underlying concepts of exclusion can only be perceived when set against its opposite: inclusion. Concerning monastic life and enclosure, Hedwig Röckelein discussing the interpretations of Niklas Luhmann, Cornelia Bohn, and Alois Hahn - stresses the ambivalent, or rather interdependent, conception of lifestyle by speaking of exclusion and inclusion at the same time (Röckelein 2014). Monastic rules did actually operate with the term inclusio, implying that a community of like-minded people was enclosed behind monastery walls where they lived a life different from that outside the walls with respect to religious practice, economy, and daily routine. When someone quit this form of life or was forced to leave the monastery, he or she would have been classified as excluded (excommunicatus) (Röckelein 2014, 129). When modern concepts are applied, one will recognise aspects of exclusion in the inclusio of monastic life. Thus Röckelein describes cloistered ascetics as 'esoteric antisocial elements' withdrawing from their ancestral social ties (family and friends). ${ }^{7}$ While this may count as one aspect of

7 Röckelein 2014, 129. For Luhmann's concept of inclusion and exclusion in stratified societies, see Luhmann 1995, 243f. and above. See also Hahn and Bohn 2002, 13-7. 
individualisation as described above, it remains obscure how individuation and individualisation are connected to this kind of exclusion. Yet traces can be found on various different levels.

First of all, with regard to the rest of society, the monk or the nun was someone special, and - I again refer to Röckelein - it was the element of voluntary exclusion that attracted social attention and generated social prestige. To accomplish this exclusion, monks and nuns were bound to a rule that regulated their whole life, subjecting them to the authority of their abbot or abbess and to the control of their brothers and sisters (Röckelein 2014, 130f.). These norms, especially the fact that the community itself was the most important feature of monastic life to which everyone had to submit, contradict the idea of monasteries as places inspiring individuation and bringing forward some process of individualisation, as Gert Melville argues. In any case, 'one of the greatest achievements of medieval monasticism, besides developing perfect forms of community, was producing structures of individuality that can be identified as breakthrough in cultural history leading towards inner self-determination'. This was possible because monasteries provided monks and nuns with the opportunity to focus on their inner relationship with God by minimising outward distractions and sensual temptations (Melville 2002, XIIf.). Living in a cloister prevents individuals from committing sins which would separate them from God (ibid. XXf., see also XXVI.). Besides, monastic life required self-reflection on different levels: the very decision to join a monastery required, in the ideal case, self-assessment and the testing of one's own spiritual strength during the novitiate. Taking the vow meant committing oneself to the community of one's own volition (ibid. XXXIIf.; cf. Melville 1996, 167ff.); in the middle of the 12th century, Premonstratensians even expected their members to follow the rules with their hearts and of their own volition (Melville 1996, 156).

Treatises dealing with the religious edification of monks, nuns, and regular canons called for self-exploration and self-inquiry, especially from the 12th century onward, during which Peter Abelard (1079-1142) composed his Scito te ipsum ('Know Thyself') (Melville 2002, XXXVIf. and XXXVIIff.; see Peter Abelard's Ethics) and the canon regular Hugh of Saint Victor (c. 1096-1141) claimed in his 'Didascalion, or, On the Study of Reading' to acquire wisdom by reading, as wisdom would facilitate self-recognition (Hugh of Saint Victor, Didascalicon, lib. 1, c. 1, 110. See Stammberger 2002, 116; Mensching 1994, 599-603.). Of course, selfreference, or rather practices of contemplation that ensured reflection about one's own inner relation to God, was a common subject of devotional texts produced for and in monasteries in the following centuries as well. Kaspar Elm, when dealing with Dominican women's convents during the 13th and 14th century, even assumes that 'religious individualism' became more important than the community 
(Elm 1992, 42f.). This may be true for some particular cases but, in general, exclusion and the relation to the outside-world, communal life, and contemplation remained equally important topics of the monastic discourse. ${ }^{8}$

To live as a recluse (in Latin and German the term inclusa/Inkluse again indicates the tension between modern and medieval terminology) can be seen as an even more radical form of voluntary exclusion. Recluses were likely to be walled up inside a cell next to the church after the liturgy for the dead was celebrated for them. During the rest of their lifetime, as far as normative sources are concerned, only a window looking inside the church allowed them to take part in the liturgy and to serve as spiritual guides for their visitors. The recluse's solitude left even more room for contemplation than that granted to monks and nuns, resulting in an even more exceptional position between society and God (cf. Herbert McAvoy 2010; Kruse 2012).

To mediate between this world and the other was the main function of saints, and the narratives of hagiography have also been the subjects of research dealing with the correlation between exclusion, inclusion, and individuality. Andreas Hammer, among others, has stressed that the future saint needed to exclude himself from the human community in this world in order to prepare himself for heavenly inclusion, i.e. inclusion in the community of saints. While the former action provided the future saint with exclusion individuality, the latter deprived him or her of individuality in any form whatever. Transcendental experiences in this world, such as visionary experiences, were taken as signs of the forthcoming heavenly de-individualisation. ${ }^{9}$ In this case, individuality and the total loss of individuality, exclusion, and inclusion, did not contradict each other but were, instead, interdependent. They thus complemented one another with regard to the hagiographical narrative (Hammer 2015, 228).

With regard to monks, nuns, recluses, and saints, voluntary exclusion served transitional purposes. Withdrawing from the secular community was supposed to enable the individual to get closer to heavenly inclusion and because of this excluded individuals could mediate between this world and the other. To a lesser degree, the logic of inclusion via exclusion is valid for private devotion as well. In all cases, exclusion leads in a certain direction, towards God. In terms of ecclesiastical concepts, this means travelling away from the Christian community in this world towards the heavenly community by moving towards the edges of Christian

8 Regarding the situation of Dominican women's convents, see, for example, Hirbodian 2016. 9 Hammer 2015, 226f. Münkler (2006, 36ff.) discusses the saints' exclusion-individuality as well. The 'overcoming' of personality and the self is also addressed in other articles, dealing with very different contexts, cf. Haas in this publication. 
society. Individuality and self-reference are to be found in between. ${ }^{10}$ Would this also be the case if the individual turned around and took a step in the opposite direction, an action that, according to ecclesiastical norms, would cause involuntary exclusion?

\subsection{Exclusion as sanction for deviant behaviour}

Before examining traces of individualisation within forms of non-voluntary exclusion and the potential of forms of non-voluntary exclusion for individuation, it is important to remember that one of the most important, if not the most important, purposes of exclusion was to keep delinquents away from the community in order to prevent 'contagion'. ${ }^{11}$ This applies both to excommunication as an ecclesiastical sentence as well as to related punishments for deviant behaviour in monastic communities (Jaser 2013, 323f., 340-8; for monastic life see Melville 1996, 163; Lusset 2011, 156). To explore the meaning of non-voluntary exclusion for individualisation and individuation, ${ }^{12}$ it is necessary to shift the focus to some extent away from the community and towards the delinquent himself, who might not have been too happy about his 'opportunity' to take part in those processes, and to his or her relation with the community.

10 This three-pole structure is important for other phenomena discussed in this publication as well. Cf. for example Cristiana Facchini 1299: 'Unquestionably, religious enthusiasm combined two distinct elements that are significant vis-à-vis religious individualization. The first one refers to the deeply personal experience of being possessed by spirits, the 'Holy Spirit', God, Christ, the divine, and which partially coincides with a religious practice related to 'mysticism'. The other one refers to the significance of the social dimension of the experience, as it was not confined to an individual experience per se, but was translated into action, meaning that it was performed within a social context and ultimately translated into a text'. Cf. Cornelia Haas' 1365 description of the 'United Lodge of Theosophists' (U.L.T.) 'method and individual approach to Helena Blavatsky's theosophy, which emphasises without exception the pursuit of the individual and its perfection - meant as an act of unification with the Divine or higher self, as well as with the community of likeminded persons, in an individual, vital way in service for humanity'.

11 Cf. Hahn 2006, 67ff., 71ff. for theoretical reflections about exclusion on account of sin and contagious diseases.

12 Britta Müller-Schauenburg's (1351) study of Benedict XIII in this publication deals with a special case of involuntary exclusion. 


\subsubsection{Norms of exclusion and traces of individualisation and individuation}

When dealing with religious and ecclesiastical norms of exclusion, it is important to keep in mind that even though two of the main characteristics of the church were its role as a social body and as a normative and even political institution, its main goal was, nevertheless, to lead the single believer to salvation (Moos 2005, 272-4). Consequently, Bohn and Hahn even find 'modern' elements within ecclesiastical concepts of exclusion that served to sanction deviant behaviour and thinking: 'In a society that designs itself according to afterlife, religion developed [...] its own patterns of exclusion. Everyone was determined by the risk of damnation: the upper class as well as the common folk. [...] the most important form of exclusion in this world that corresponded to afterlife was excommunication; it could strike a nobleman and even an emperor. The worst exclusion of all leads to eternal hell: Religion within the stratified society anticipated modern settings of inclusion and exclusion, because religion constituted an early form of a differentiated functional system that included everyone in the first place and secondly promoted individuation. The individual, not a collective, is to be redeemed and damned' (Hahn and Bohn 2002, 15; likewise Bohn 2006b, 147f.; Bohn 2006a, 37f.). Bohn and Hahn seem to echo Moos' statement that Luhmann's model needs to be turned upside down with regard to canon law (Moos 2005, 271-88). They furthermore clearly refer to a macroscopic level, thus it shall be discussed if individuation and individualisation can also be found when going into detail. Let us first consider norms of exclusion as a sanction with the aim to correct deviant individuals.

Monastic rules and consuetudines ('customaries') included various forms of exclusion to correct errant monks and nuns as well as lay brothers and sisters. The abbot (or the abbess) could separate the deviant from the dormitory, exclude him or her from communal meals and work or even mass (excommunication). In severe cases one could be imprisoned or - in the worst case - even expelled forever. ${ }^{13}$ Some communities and Orders that had developed a central organisation managed to gain even the penal jurisdiction over monks usually held by the bishops (see for example Füser 2000, 43ff.), including excommunication as legal punishment. When exclusion is seen as a medicine to cure the deviant who drifted away from the norms of monastic life, its benefit for the soul of the

13 Röckelein 2014, 129, 134-8. Füser 2000, 65-9, 76-80, 87-90, 100, 124-8, 139ff., 152-7, 186-90, 205ff., 214, 220, 224ff., 232ff., 245f., 248ff., 296ff., 304-9, 311, 316f. Monastic rules and synodal statutes refer to the imprisonment of delinquent monks from late Antiquity onwards; from the 10 th century onwards, some consuetudines of canons regular deal with the subject as well, see Lusset 2011, $154 \mathrm{ff}$. 
individual is obvious, as the rules were thought to enable the individual to unite with God. But exclusion may also have contributed to the individual's individuation on another level. Megan Cassidy-Welch, speaking of Cistercian monasteries, assumed that even incarceration served as something more than 'punishment'. It was also intended to remind the sinner of the merits deriving from 'ascetic practice and the cenobitic life' (Cassidy-Welch 2001, 25). She adds that, in a way, 'incarceration was not necessarily solitary: the prisoner was able to commune with God and rediscover the means to eternal liberty' (Cassidy-Welch 2001, 41). Thomas Füser comes to a similar conclusion when comparing normative sources of Benedictine, Cistercian, and Cluniac origin up to the 14th century: 'in every day monastic life, punishments mark central points for defining one's own spiritual progress' (Füser 2000, 328).

Norms of excommunication for deviant behaviour are known in Christian communities from the New Testament onwards. They applied not only to monks and nuns but also to clerics and the laity. The censure experienced a changeful development throughout the centuries up to the 12th century that cannot be described here (see Vodola 1986, 1-27). The basic idea was that a severe sin separated the sinner from God, a view that was expressed by separating the sinner from the sacraments or even the Christian community and, in doing so, forcing the sinner to amend and to return to the bosom of the church. During the 12th and 13th centuries, some fundamental specifications with regard to the role of the individual were collected or established and discussed in canon law. They can be found in the private collection of Gratian (Decretum Gratiani, ca. 1140) and in official canonical collections such as the Liber Extra (1234) and the Liber Sextus (1298). We learn from those sources that one could be sentenced with excommunication, for instance, for disobedience to prelates, for violating ecclesiastical rights and possessions, for injuring clerics, for infringements of norms concerning marriage and sexuality, for maintaining contact with an infidel or for practicing magic (Decretum sive Concordia discordantium canonum, C. 11 q. 1 c. 12, C. 12 q. 2 c. 4 , C. 17 q. 4 c. 23 , C. 24 q. 3 c. 19 , C. 2 q. 6 c. 32 , C. 26 q. 5 c. 9). Minor sins and offences resulted in a minor excommunication (exclusion from the sacraments); major sins and offences entailed a major excommunication (exclusion from the sacraments and the community of believers in a broad sense, as common and economic life, legal rights, and feudal ties were affected to varying degrees) (see for example Liber Extra, 2.25.2; 5.27.10, cf. Vodola 1986, 44-96). Even though some scholars tend to understand excommunication as a mere disciplinary punishment (cf. Vogel 1975, 446), we have to bear in mind that in contemporary legislation it was meant to provide inner spiritual healing as long as the excommunicated individual faced the sentence with respect (see for example Dekrete der ökumenischen Konzilien 2. First council of Lyon 1245, const. 19, 291). 
Some developments in canon law shed light on strong tendencies towards standardisation yet, at the same time, point to new perspectives for the individual. Excommunication for certain offences required an ecclesiastical judge's sentence, whereas other offences automatically and immediately led to excommunication. Canonists and popes deliberated on the latter form of exclusion particularly in the 12th century. In some respects, this differentiation helped increase papal control; in certain cases, e.g. when the excommunicate had beaten a cleric, only the pope could grant absolution (Vodola 1986, 28-31; Dekrete der ökumenischen Konzilien 2. Second council of the Lateran, can. 15, $200=$ Decretum sive Concordia discordantium canonum, C. 17 q. 4 c. 29). With regard to heresy, excommunication ipso facto could be used to uncover cases of erratic religious behaviour that perhaps otherwise would not have been detected. If people from the delinquent's personal environment knew about the excommunication ipso facto, they were obliged to avoid contact with the delinquent. The delinquent's priest, for example, was not allowed to administer the sacraments to him. Thus competent ecclesiastical judges were able to read the signs and take the case to the court (Vodola 1986, 34). But, nevertheless, this so called excommunicatio latae sententiae first and foremost concerned the excommunicated individuals themselves, who were thrown back on themselves and their consciences. ${ }^{14}$ Besides, in less serious cases, such as when someone had made contact with an excommunicate, this form of penalty granted a certain amount of privacy: the person concerned could make his confession to a simple priest and attain absolution without undergoing a process and appearing in court (Liber Extra, 5.39.29). The concept of general excommunication, i.e. on certain days ecclesiastical judges sentenced everyone in general who committed a certain crime or would commit it in future (cf. Huizing 1955, 315-8; Jaser 2013, 359-73), prima facie seems to provide striking evidence for a process of de-individualisation. But Dominique Iogna-Prat draws attention to the fact that since 1246 at the latest the practice of excommunicating collectives had been abandoned. The ecclesiastical judges were pledged to judge and punish only individuals with this sentence, thereby acknowledging their personal responsibility (Iogna-Prat 2005b, 20; Liber Sextus, 5.11.5). Peter D. Clarke traced similar discussions and norms concerning the interdict, a censure that prohibited groups, such as the citizens of a certain town, from participating in the rites and services of the church (Clarke 2007, 21-7).

Speaking of personal responsibility and culpability, the ecclesiastical process dealing with excommunication allowed reflection upon the question of whether

14 As von Kober puts it, excommunicatio latae sententiae prevails 'nur vor Gott und dem Gewissen', Kober 1857, 51. 
or not the penalty was imposed justly. Apart from the fact that the culprit was able to appeal against a sentence (cf. Hergenröther 1875; Köbler 2014, 296ff.) and to give his or her opinion in this regard, the mere idea that a sentence could be unjust inspired popes and scholars to reflect upon the relation between the church, the status of the sinner, and God. We learn from the Decretum Gratiani that God's judgement will not be affected by an unjust sentence, because Gods judgement relied upon the individual's conscience exclusively (Decretum sive Concordia discordantium canonum, C 11 q. 3 c. 54). Though, in general, the excommunicate was obligated to respect even an unjust sentence until it was lifted, he or she was allowed to disregard it when it forced him to act wrongfully or to disobey Gods commandment (Decretum sive Concordia discordantium canonum, C. 11 q. 3 d. p. c. 90, c. 95, d. p. c. 101. Cf. Helmholz 1982, 211). In consequence, this left room for personal considerations about religious principles, at least on a level still compatible with the orthodoxy. The same applied to an excommunicate's fellows. While they were in fact obliged to avoid contact with someone struck with a sentence of major excommunication, they were allowed to decide if they avoided someone condemned unjustly, as long as they were led by their conscience (Gillmann 1924, 7).

Excommunication was intended to bring the excluded individual to voluntarily reintegrate himself or herself into the church. As such, it was a sanction that could and should be removed after a time. During the phase of excommunication, the intention was that something should happen to the individual's inner attitude towards God and towards the Christian community. Whether what happened was sufficient or not needed to be judged, and it was judged within the process of absolution. Ecclesiastical judges needed outward signs to evaluate the inner state of a culprit, to condemn him or to lift the sentence. Concerning absolution, it was confession, ${ }^{15}$ a pledge to improve and to make amends, sometimes in terms of public penance, that served this function. Concerning practice, we are well informed about the excommunicates' pledges and public acts of obedience and penance (cf. Neumann 2008; Mansfield 1995), i.e., those actions directed towards the Christian community. Unfortunately, the act of confession, which was more explicitly directed towards the sinful individual, remains obscure. We nevertheless have to take into account that in some, or even many, cases some kind of confession might have taken place, even though we do not know what the individual and his confessor talked about. The impact of confession on

15 Confession was required at least when a confessor absolved an excommunicate in the face of death, see Swanson 2011, 9ff. In some cases, confession was also required when an excommunicate was to be absolved regularly, see Mersch 2017, chapter IV 2.3. 
individualisation and individuation is highly ambiguous. As has been pointed out by Nicole Reinhardt in the context of early modern confession, confession was embedded within a highly normative framework and committed the individual to this normative framework. Nevertheless, confession drove individuals to self-examination, to think about their intentions and conscience (Reinhardt 2015, 424; see also Münkler 2009, 25-8, Münkler focuses on confession's contribution to processes of normalisation). This ambiguity can be observed in medieval times as well, ${ }^{16}$ although the normative frameworks and modes of self-examination were subject to fundamental historical changes until the 16th and 17th centuries. However, Alois Hahn, referring to the changes confession underwent since the 12th century and quoting publications from across the range of the aforementioned fields within medieval studies, has claimed that in this case 'subjectivity results from processes of social control' (Hahn 1997, 409).

Assuming that Hahn's viewpoint is valid, a similar ambiguity can be observed when exploring phenomena of exclusion. Exclusion usually did not correspond to an exclusion from society but, rather, played a crucial role as a means of regulation within society (Bohn 2013, 79). This observation is important for understanding the impact of phenomena of exclusion on modes of individuation and processes of individualisation that were, in turn, connected to the institution of confession. When thinking about individualisation and individuation, a point of particular interest is the privacy of auricular confession postulated at least since 1215. But it should be noted, too, that confession is based upon an even more complex aspect of Christian thinking, namely the concept of sin. In theology and canon law, the question of individual intention became increasingly important. Again, it is the 12th century that is most commonly seen as the period of upheaval (Schmitt 2001, 251). Hahn and Bohn, for example, refer to Abelard, who in his Scito te ipsum shifted the focus from exploring external action in order to detect sin towards intentional action, i.e., acts of the will consisting in consent to sin. For Abelard, atoning for one's sin therefore presupposed internal contrition, 'contrition of the heart' (contritione cordis). ${ }^{17}$ Although it had been common to explore one's own internal state with regard to sin at least since Augustine (d. 430), the

16 Arlinghaus 2015, 10ff. with reference to relevant previous studies. For correlations between sin, conscience, norms, and deviance in 12th and 13th century monasticism, see Melville 1996, 172-82, Melville 2005, 186f. For the impact of ecclesiastical theories of intention on statements of defendants before ecclesiastical courts in the 14th century, see Mersch 2018.

17 Hahn and Bohn 2002, 11f. with reference to Peter Abelard's Ethics, c. 3, 4-37, and c. 19, 88f.: Cum hoc autem gemitu et contritione cordis, quam ueram penitentiam dicimus, peccatum non permanet [...] - 'Moreover, with this sigh and contrition of the heart which we call true repentance sin does not remain [...]'. See also Kramer and Bynum 2002, 65-71 with reference to further sources. 
particular emphasis on introspection from the 12th century onwards may be explained by reference to the 'birth of purgatory' during that time, leading to a broader acknowledgement of the individual's responsibility for him- or herself (Kehnel 2002, 36 with reference to Le Goff 1981). In canon law, scholars debated about whether collectives were able to sin in the form of consenting to another's sin or if this was possible only for individuals (Clarke 2007, 27f.). This would imply that various phenomena grouped around concepts of sin may be enlightening subjects for the issue discussed in this paper, since sin entails sanction. Furthermore, absolution required inner contrition and this was true not only with regard to 'private' and regular confession but also with regard to an absolution from excommunication.

When comparing forms of voluntary exclusion, such as those sketched above, with the norms of involuntary exclusion, a number of essential differences can be observed. As already stated above, while monastic and saintly withdrawal from the world was supposed to bring an individual closer to God and enable him to serve as a link between this world and the other, the exclusion of sinners was believed to express their distance from God. With regard to the legislative setting, the sinner was of no positive use for the community of believers. Nevertheless, we can observe several similarities as well. Both types of exclusion have sometimes been understood in the scholarship as liminal conditions (concerning monasticism, see Röckelein 2014; concerning excommunication see Jaser 2013, 322-8). In either case, this condition was thought to be temporal, as inclusion was its final aim; ${ }^{18}$ monks, nuns, and saints would aim to unite with God while excommunicates should reintegrate themselves into Christian society. Furthermore, in both cases, although a strict set of norms shaped the relevant condition, it offered and demanded individual self-reflection and reflection on one's inner relation to God. In the case of excommunication, concepts of guilt and conscience shaped this reflection. In the next chapter, we will see that these ideas had an influence on historical agents as well.

\subsubsection{Being excluded and talking about excluded individuals}

When examining individual cases of excommunication, with regard to the source material, we are far better informed about the prelates who excluded deviant subjects than about how penalised individuals reacted to their exclusion. Where we do have information we can mainly trace legal procedures that point towards

18 Cf. Hahn 2006, 71: 'Soziologisch sind diese partiellen Formen der Exklusion deshalb relevant, weil sie Inklusion und Exklusion in spannungsvoller Weise miteinander verknüpfen müssen'. 
conflicts we today would assign to the field of politics, as in many cases command structures or ecclesiastical properties were concerned. But from time to time we find examples that hint at individuation and individualisation in responses to ecclesiastical censures or in sources that talk about excommunicated individuals. In what follows, a number of examples will be discussed in order to show to what extent excommunication could initiate or enforce processes of individuation and to what extent talking about the excommunicate's inner state could serve as a means of standardisation.

With regard to appeals against excommunication, from the 12th century onwards we often read about procedural errors, ill-informed judges, and misconduct. This is true, for instance, in the case of English bishops appealing against a sentence imposed by Thomas Becket (d. 1170), archbishop of Canterbury, during the Becket-controversy in 1166 (Materials for the history of Thomas Becket 5, no. 204, 403-8. Cf. Helmholz 1994, 242ff.); in the case of laymen who had been excommunicated in the context of quarrels with clerics during the Middle Ages ${ }^{19}$; in the case of appeals during the conflict between the Colonna-cardinals and Pope Boniface VIII in 1297 concerning his administration and election (Becker 1988, 54-9); and in the case of monks and abbots appealing against charges of apostasy in the 15th century (Svec Goetschi 2015, 231-59).

What do we learn in these instances about an excommunicated individual's internal state, about his or her personal relation to God? In many cases, we find that the excommunicated person presented his or herself as a good Christian who did his very best to fulfil his role in Christian society as a bishop, monk, nun, king, or layman holding a special office. And in some cases, those appeals served propagandistic purposes. Some of the most popular examples - at least with regard to German medieval studies - are those related to King Louis IV 'the Bavarian' (d. 1347). After a double election and the subsequent disputes about the papal ratification of Louis' kingship, Pope John XXII excommunicated Louis in March 1324 and imposed an interdict on the Empire. Three texts illustrating the development of Louis' argument from December 1323 onwards suggest that he planned to appeal before and after the sentence was imposed. ${ }^{20}$ He insisted on his election and kingship being legitimate, portrayed himself as a sincere catholic believer and ruler, pointed out legal errors in the process of his excommunication, and tried to demonstrate that John XXII was an unjust and illegitimate

19 Cf., for example, the appeal filed by the city of Soest in 1280 against a sentence of excommunication imposed on the citizens by Siegfried of Westerburg, Archbishop of Cologne, Westfälisches Urkundenbuch 7, no. 1726, $795 \mathrm{ff}$.

20 Among the numerous studies dealing with those connections, Becker's book about appeals should be mentioned in particular, Becker 1988, 72-99. 
judge. Concerning this last aspect, Louis at first criticised John's treatment of the Friars minor (December 1323, Monumenta Germaniae Historica. Constitutiones 5, no. 824, 641-7, the passage concerning the Friars minor: 646), before setting aside this argument in the second text (January 1324, Monumenta Germaniae Historica. Constitutiones 5, no. 836, 655-9), and going on to accuse John of being a heretic with a thirst for spilling Christian blood in the last text (May 1324) composed after his excommunication. The argumentation includes references to the understanding of evangelical poverty held by the Friars minor (Monumenta Germaniae Historica. Constitutiones 5, no. 909f., 723-54; see for example Wittneben 2003, 229ff.), a highly controversial subject within the Order and the church at that time which led to papal processes, doctrinal decisions, and various appeals. ${ }^{21}$ Louis promulgated this appeal throughout the Empire (see for example Kaufhold 1994, 66-9), from which we can see that it was composed not just as legal remedy in the ecclesiastical court but also to serve a propagandistic purpose.

When people were excommunicated during a dispute over religious ideas and doctrine, the dispute might be shifted to the question of whether the individual should obey his prelate or - if the prelate was wrong - follow his conscience and disobey. This can be observed, for instance, with regard to the above-mentioned dispute between the Friars minor and the Pope. However, those conflicts are more general, the texts may only briefly touch on the topic of conscience, the authors mostly appeal not against censures but against papal bulls dealing with doctrine, and they stress their main subject - for example evangelical poverty rather than excommunication or the appellants' internal state (cf. for example Wittneben 2003, 282ff., 290-352 on the Friars' minor appeals from Avignon and Pisa [1328], on the topic of conscience especially 309; Wittneben 2004; Becker 1988, 72-83). Appeals allow us, then, to look at how excommunicates evaluated ecclesiastical hierarchies as well as their position and the judge's position within these hierarchies and how they dealt with ecclesiastical norms. Here one might speak of 'inclusion individuality' in the state of exclusion, since the appellants related themselves to the norms and ideals of the Christian community. The personal relationship the excluded maintained with God seems to be less important than the individual's place within Christian society, the judges' misconduct, and in some cases the intentions the (future) excommunicate describes when explaining that behaviour led to excommunication.

21 Cf. Miethke 1969, 76f., 86, 105 note 390, 403-6, 409f., 416, 424, 429, 501, 505, 517 with information about the appeals of Louis IV, those of the Friars minor, and the correlations between those texts. 
With regard to this last aspect, the strategies excommunicates used to legitimise their behaviour sometimes seem to slightly foreshadow 'modern' role-distance. When, at the end of the 15th century, the Pope excommunicated Johann of Morschheim, a palatine bailiff, Johann excused his behaviour with reference to the specific context. The actions which led to his excommunication were embedded in a conflict between his superior, Philip, Elector Palatine of the Rhine, and the abbot of Weissenburg abbey, who were fighting over possessions. Johann 1498 tried to gain support for the annulling of the sentence by declaring in a plea that he had not attacked the abbey of his own will but due to his duties as a bailiff. ${ }^{22}$ Overall, appeals may shed light on how the excommunicates perceived themselves as legal persons or at least acted like one. But this seems to lead us too far away from the aspects dealt with in medieval studies when speaking of individuation, the individual, or the self.

When an individual ruler or city consul ignored a major excommunication, or when it was likely that he would ignore it, ecclesiastical judges could impose an interdict on the excommunicates' lands. Here again, sources inform us about the reactions of the aggrieved parties, and here again I want to draw on the example of Louis IV. As I have argued elsewhere with reference to the Dominican mystic Margaretha Ebner and the Benedictine monk Hugh of Geurtheim during the reign of Louis IV, the interdict could press people to criticise norms and judgements (Mersch 2013). As Louis was never granted absolution, the interdict was - or should have been - in force throughout more than two decades in large parts of the Empire. Hugh's convent, taking the king's side, ignored the censures. Hugh himself changed his mind in 1338 and went to the papal court in Avignon to ask for absolution. He also pleaded to be allowed to break his vows by not returning to the monastery in Gengenbach so long as the interdict lasted, a request his Benedictine superiors supported and which the curia finally granted. As Martin Kaufhold puts it, Hugh was able find his own way out of the above mentioned predicament (Kaufhold 1994, 248f.; Vatikanische Akten no. 1988, 719f.); his conscience seems to have made him act against the opinion prevailing in his convent. Margaretha Ebner's case proves that such individual decisions could be based upon reflection of one's own internal attitude. When she composed her 'Revelations' in the period after 1344 in order to describe her life shaped by the mystical vocation, Margaretha used the excommunication of Louis IV and the following interdict to ponder two questions: Is it possible to act on the basis of one's

22 A summary of Johann's plea by Konrad Peutinger († 1547) can be found in Deutsche Reichstagsakten. Mittlere Reihe 6, no. 146, 597f.: He said he was ein amptman der Pfaltz gewesen, und deshalben seins ampts, was er wider den stift gehandlet, hette tun müssen, nicht us sein sunderlichen willen noch vornehmen. 
own free decision when the decision contradicts the commands of a prelate? And if it is possible, why is it possible? The answer she received when asking the infant Jesus himself was quite straightforward: yes, it is possible because true love for god outweighs the duty to obey. It would, therefore, be possible to receive communion even during the interdict, as long as the individual sought to do so out of love for God. At the end of her 'Revelations' she reinforces her argument. 'Human judgement is', as the infant Jesus told her, 'often deceived' (Margaretha Ebner. Offenbarungen 28, 35f., 148), and the interdict is in fact merely a penalty to support the judgement of a human being, even though this human being might be the pope. ${ }^{23}$ The two examples illustrate that in situations affected by censures of exclusion it is possible to detect individual decisions that may be based on internal reflection.

With regard to absolution, we often learn that the former excommunicate felt contrition. When the citizens of Magdeburg, for example, were on their way to be reconciled some five or six years later after Archbishop Burchard III was murdered in the city in 1325, the city's representatives went to the curia and shed tears to express their contrition (Urkundenbuch der Stadt Magdeburg 1, no. 339, 205-9). In addition, some excommunicated consuls wrote about their deep regret in separate letters addressed to the pope (Päbstliche Urkunden und Regesten, no. 512, 283f.; Urkundenbuch der Stadt Magdeburg 1, no. 336, 203f., cf. Mersch 2018). We do not know whether the future reconciled delinquents really felt this way or if they only tried to comply with ecclesiastical norms. Nevertheless, it is obvious that the delinquents' internal states were a subject of discourse.

This was the case not only in court rooms but also in historiography. As indicated above, in the 11th and 12th centuries the excommunicated King Henry IV was depicted in a way that laid emphasis on the inner condition of the individual (Bagge 2002, 308 and 363). Concerning Henry's famous penance and reconciliation at Canossa, where he sought out Pope Gregory VII in 1076/1077, chroniclers wondered if his penance was honest or if he only pretended contrition. Philippe Buc has gathered together the sources dealing with this episode and points out

23 This addresses a tension that is actually effective up to date, cf. Veronika Hoffmann's remarks in this publication on contemporary German Christianity: 'The key problem lies not in differences at the level of belief content [...] but between the institutional view of an interconnectedness of religious truth claims, the authority of the church, and institutional belonging and the individual view of radical religious self-empowerment. Because this tension is to be found within the institutions, religious self-empowerment and belonging to institutions that are theoretically incompatible in fact go together to a large extent' (1121). For the correlation between deviance, processes of impiety, and personal choices, especially concerning the deviant's followers, cf. Jan Bremmer's contribution to this publication. 
that some authors pondered the question of whether the penance reflected an inward view or not. The contemporary Benedictine monk Hugh of Flavigny provided his readers with a harsh description of Henry's attitude on the grounds that Henry had obtained absolution only on account of his outward appearance. Hugh stressed that someone 'who only pretends to look for God does not deserve to find him' (Buc 2001, 243; Hugh of Flavigny. Chronicon, lib. 2, 444f.). Bonizo of Sutri, an adherent of Gregory VII, reminded his readers that penance needs to be done with a humble mind and body (mente ut corpore), implying that Henry performed the penance only with his body and not in his mind (Buc 2001, 243; Bonizo of Sutri. Liber ad amicum, lib. 8, 610). Similar examples can be found in sources from the 12th and 13th centuries and in sources dealing with less popular people, too (cf. Mersch 2017, chapter IV 1.3a and 2.4). Concerning the 14th century, the example of Louis IV shows that even someone who died without reconciliation could be depicted in a positive way with regard to his internal state. Louis was never reconciled and he died in 1347 as an excommunicate (Czerny 2005, 81f.) who, according to canon law, was dissociated from the church and therefore separated from God, not only in this world but in the other as well. Many sources describe how Louis died from a stroke during a hunt (cf. Czerny 2005, 34-48; Glaser 2002, 1-37). Pope Clement VI then condemned the dead emperor, calling him a 'persecutor and enemy of God and the Roman church', ${ }^{24}$ and some contemporary chroniclers did the same by reflecting on signs of Louis' internal state. For example, Henry of Rebdorf, a canon from Eichstätt, pointed out that Louis had died without any signs of penance or contrition (Henry of Rebdorf. Chronik, 68f.). In contrast, we read in the 'Life of Emperor Louis IV', presumably written in 1347, that the 'good catholic' Louis died while 'lifting his hands and eyes to the sky, recommending himself humbly to God and the Virgin Mary' (Chronica Ludovici imperatoris quarti, 137). According to a contemporary Bavarian continuation of the 'Saxonian World Chronicle', Louis' companions witnessed that, in his last breath, he said a short prayer addressed to the Virgin Mary. ${ }^{25}$ The Dominican friar Henry of Herford reported that Louis had spoken words of penance, his hands and eyes directed towards the sky: 'Almighty and merciful Lord, have mercy on me, the poor sinner, because although I have truly sinned a lot, anyway, I have never ever renounced you, God of mercy, or belief or vow, as you know'. Having

24 In a letter addressed to Bishop Ulrich of Constance, November 13th 1347, and again in a letter addressed to King Charles IV, December 7th 1347: dampnate memorie Ludovici de Bavaria, dei et ecclesiae Romane persecutoris et hostis, Vatikanische Akten, 848f. Cf. Czerny 2005, 72f.

25 Sächsische Weltchronik. Zweite bayerische Fortsetzung, 339. Michael de Leone tells a similar story, Michael de Leone. De chronicis temporum hominum modernorum, 472f. 
said this, he then died (Henry of Herford. Liber de rebus memorabilioribus, ad a. 1347, 270f.).

For the approach pursued in this paper, the chroniclers' interest in Louis' internal or mental state is important with regard to the concepts of sin and penance. Susan Kramer and Caroline Walker Bynum, referring to the 12th century, point out that 'man cannot see what is hidden [...]. This privileging of the inner self is [...] the root of the disclaimer frequently cited in twelfth-century treatments of penance that the church judges exterior things while God alone judges what is hidden or secret. The church does not know the soul of even an open excommunicate or heretic who is seized suddenly in death, for example [...]. Nevertheless, despite this admitted inability to see into the soul, the church does retain an interest in knowing the interior homo' (Kramer and Bynum 2002, 71). Apparently, excommunicates' contemporaries in general retained an interest in knowing the inner man. When taking into account the fact that at least some of the chroniclers may have had a didactic purpose, using the story to tell their readers how to die a 'good death', and thereby explaining how even an excommunicated individual could achieve heavenly inclusion, ${ }^{26}$ discursive elements of individualisation seem to have been used here to spur religious standardisation.

Taken together, the statements of excommunicated individuals and individuals from the excommunicate's environment, as well as reports about excluded individuals within historiography, bear resemblance to the norms of exclusion sketched above. The strict set of norms shaped how these people talked about themselves and about excommunicated individuals. In turn, the way in which they talked helped to reinforce processes of standardisation. Nonetheless, the individual's inner state was at stake and sources related to excommunication can thus shed light on how people thought about this internal state and found means to talk about it.

\section{Conclusion}

Both self-exclusion and involuntary exclusion demarcate states of being that relate the individual to society in a very specific way and, at the same time, to God in an equally particular way. Whereas self-exclusion should lead towards God and therefore pave the way to heavenly inclusion, involuntary exclusion should, above all, illustrate the individual's distance from God. But on another

26 For the correlation between the particular judgement, the individual, and inclusion in general see Hamm 2016, 290ff. 
level it should also persuade the sinner to reintegrate into the church or, in other words, to again achieve inclusion in the church, a this-worldly inclusion eventually paving the way to heavenly inclusion. Consequently, in both cases strict norms were developed that should guide the individual on his or her way. And exclusion could be made visible in terms of temporal or permanent spatial separation: one could contemplate in a 'private' room, live in enclosure, be walled away inside a separate room, or even be banned from the mass and, therefore, from (certain parts of) the church building. In both cases - voluntary and involuntary exclusion - guidance was available in terms of discourses about the internal state. This could be found in treatises dealing with the religious edification of monks and nuns or, for example, in historiographical texts dealing with the internal state of sinners. In both cases, standardisation and individualisation are not mutually exclusive but mutually dependent. Although exclusion as a means of religious standardisation via 'punishment' may seem to be in conflict with the notion of individualisation because it appears as a measure of compulsion, it could still provide starting points for the individuation of an individual. Canon law expected that those threatened by excommunication and those being excommunicated exercised introspection and self-reflection to prepare to reintegrate into the Christian community. Furthermore, it had the potential to contribute to a process of individualisation because the implementation of ecclesiastical penalties provoked protests and discussions about whether these penalties had to be accepted and why, which is to say that individuals had to choose whether to obey a judgement or to deal with it in a rather stubborn way. On the level of discourse, then, excluded individuals could serve as figures onto whom debates could be projected, allowing the discussion of ideal forms and modalities of self-reflection and the internal relationship with God.

\section{References}

\section{Primary sources}

Bonizo of Sutri. 'Liber ad amicum'. In Monumenta Germaniae Historica Scriptores. Libelli de lite imperatorum et pontificum saeculis XI. et XII. conscripti 1, eds. Ernst Dümmler, Lothar von Heinemann and Friedrich Thaner, Hanover: Hahn 1891.568-620.

'Chronica Ludovici imperatoris quarti.' In Bayerische Chroniken des 14. Jahrhunderts (Chronicae Bavaricae saec. XIV.) Monumenta Germaniae Historica. Scriptores Rerum Germanicarum in usum scholarum 19, ed. Georg Leidinger, Hanover: Hahn 1918. 119-38.

Decretum sive Concordia discordantium canonum. Corpus luris Canonici 1, ed. Emil Friedberg, Leipzig: Tauchnitz 1879-1881. 
Dekrete der ökumenischen Konzilien 2: Konzilien des Mittelalters: vom ersten Laterankonzil (1123) bis zum fünften Laterankonzil (1512-1517), ed. Josef Wohlmuth, Paderborn: Schöningh 2000.

Deutsche Reichstagsakten. Mittlere Reihe 6: Reichstage von Lindau, Worms und Freiburg 1496-1498, ed. Heinz Gollwitzer, Göttingen: Vandenhoeck \& Ruprecht 1979.

Henry of Herford. Liber de rebus memorabilioribus sive chronicon Henrici de Hervordia, ed. August Potthast, Göttingen: Dieterich 1859.

Henry of Rebdorf (Heinrich Taube von Selbach). Chronik. Mit den von ihm verfaßten Biographien Eichstätter Bischöfe (Chronica Heinrici Surdi de Selbach). Monumenta Germaniae Historica Scriptores Rerum Germanicarum. Nova series 1, ed. Harry Bresslau, Berlin: Weidmann 1922.

Hugh of Flavigny. 'Chronicon'. In Chronica et gesta aevi Salici. In Monumenta Germaniae Historica. Scriptores in Folio 8, ed. Georg Heinrich Pertz, Hanover: Hahn 1848. 288-502.

Hugh of Saint Victor. Didascalicon de studio legendi: lateinisch-deutsch = Studienbuch. Fontes Christiani 27, ed. Thilo Offergeld, Freiburg: Herder 1997.

'Liber Extra.' In Decretalium Collectiones. Decretales Gregorii p. IX. Corpus luris Canonici 2, eds. Aemilius Ludwig Richter and Emil Friedberg, Leipzig: Tauchnitz 1881.1-928.

'Liber Sextus.' In Decretalium Collectiones. Decretales Gregorii p. IX. Corpus Iuris Canonici 2. eds. Aemilius Ludwig Richter and Emil Friedberg, Leipzig: Tauchnitz 1881. 929-1124.

Margaretha Ebner, Henry of Nördlingen. Offenbarungen und Briefe. Ein Beitrag zur Geschichte der deutschen Mystik, ed. Philipp Strauch, Freiburg im Breisgau: Mohr 1882.

Materials for the history of Thomas Becket, archbishop of Canterbury (canonized by Pope Alexander III., A. D. 1173.) 5: Epistles, I.-CCXXVI. Rerum britannicarum medii aevi scriptores or Chronicles and Memorials of Great Britain and Ireland during the Middle Ages 67.5, ed. James C. Robertson, London: Longman 1881.

Michael de Leone. 'De chronicis temporum hominum modernorum.' In Fontes rerum Germanicarum. Geschichtsquellen Deutschlands 1, ed. Johann Friedrich Böhmer, Stuttgart: Cotta 1843. 466-79.

Monumenta Germaniae Historica. Legum sectio IV. Constitutiones et acta publica imperatorum et regum 5. Inde ab a. MCCCXIII usque ad a. MCCCXXIV, ed. Jacob Schwalm, Hanover: Hahn 1909-11.

Päbstliche Urkunden und Regesten aus den Jahren 1295-1352, die Gebiete der heutigen Provinz Sachsen und deren Umlande betreffend. Geschichtsquellen der Provinz Sachsen und angrenzender Gebiete / Geschichtliche Vereine der Provinz Sachsen 21, ed. Gustav Schmidt, Halle: Hendel 1886.

Peter Abelard's Ethics. An edition with introduction, English translation and notes by David Edward Luscombe, Oxford: Clarendon Press 1971.

'Sächsische Weltchronik. Zweite bayerische Fortsetzung'. In Sächsische Weltchronik. Eberhards Reimchronik von Gandersheim. Braunschweigische Reimchronik. Chronik des Stiftes S. Simon und Judas zu Goslar. Holsteinische Reimchronik. Monumenta Germaniae Historica. Deutsche Chroniken 2, ed. Ludwig Weiland, Hanover: Hahn 1877.

Urkundenbuch der Stadt Magdeburg 1: bis 1403, ed. Gustav Hertel, Halle an der Saale: Hendel 1892.

Vatikanische Akten zur deutschen Geschichte in der Zeit Kaiser Ludwigs des Bayern, ed. Sigmund Riezler, Innsbruck: Wagner 1891.

Westfälisches Urkundenbuch 7. Die Urkunden des Kölnischen Westfalen 1200-1300, ed. Staatsarchiv Münster, Münster: Aschendorff 1901-8. 


\section{Secondary sources}

Aertsen, Jan A. 1996. 'Einleitung: Die Entdeckung des Individuums'. In idem and Andreas Speer (eds.). IX-XVII.

Aertsen, Jan A. and Andreas Speer (eds.). 1996. Individuum und Individualität im Mittelalter. Berlin: De Gruyter.

Arlinghaus, Franz-Josef. 2015a. 'Conceptualising Pre-Modern and Modern Individuality: Some Theoretical Consideration'. In idem (ed.). 1-46.

Arlinghaus, Franz-Josef (ed.). 2015b. Forms of Individuality and Literacy in the Medieval and Early Modern Periods. Utrecht Studies in Medieval Literacy 31. Turnhout: Brepols.

Bagge, Sverre. 2002. Kings, politics, and the right order of the world in German historiography c. 950-1150. Studies in the history of Christian thought 103. Leiden: Brill.

Becker, Hans-Jürgen. 1988. Die Appellation vom Papst an ein allgemeines Konzil: historische Entwicklung und kanonistische Diskussion im späten Mittelalter und in der frühen Neuzeit. Forschungen zur kirchlichen Rechtsgeschichte und zum Kirchenrecht 17. Cologne: Böhlau.

Bohn, Cornelia. 2006a. 'Inklusions- und Exklusionsfiguren'. In idem (ed.). 141-56.

Bohn, Cornelia. 2006b. Inklusion, Exklusion und die Person. Theorie und Methode: Sozialwissenschaften. Konstanz: UVK Verlagsgesellschaft.

Bohn, Cornelia (ed.). 2006c. Processi di inclusione ed esclusione: identità ed emarginazione = Prozesse der Inklusion und Exklusion: Identität und Ausgrenzung. Annali di sociologia/ Soziologisches Jahrbuch 16, 2002/2003, ed. idem, Milan: Angeli.

Bohn, Cornelia. 2013. 'Ungleichheit, Devianz und Differenzierung. Paradigmen der Inklusionsund Exklusionsforschung'. In Facetten der Prekarisierungsgesellschaft. Prekäre Verhältnisse. Sozialwissenschaftliche Perspektiven auf die Prekarisierung von Arbeit und Leben. Gesellschaft der Unterschiede 9, ed. Oliver Marchart, Bielefeld: transcript Verlag. 71-90.

Bohn, Cornelia and Alois Hahn. 2002. 'Patterns of Inclusion and Exclusion. Property, Nation and Religion', Soziale Systeme. Zeitschrift für soziologische Theorie 8. 8-26.

Buc, Philippe. 2001. The dangers of ritual: between early medieval texts and social scientific theory. Princeton: Princeton University Press.

Buc, Philippe. 2010. 'Die Krise des Reiches unter Heinrich IV., mit und ohne Spielregeln. "Par malvais roi est mains frans hom honnis” (Raoul de Cambrai, v. 650)'. In Die Spielregeln der Mächtigen: mittelalterliche Politik zwischen Gewohnheit und Konvention, eds. Claudia Garnier and Hermann Kamp, Darmstadt: Wissenschaftliche Buchgesellschaft. 61-94.

Cassidy-Welch, Megan. 2001. 'Incarceration and Liberation: Prisons in the Cistercian Monastery', Viator 32. 23-42.

Clarke, Peter D. 2007. The interdict in the thirteenth century: a question of collective guilt. Oxford: Oxford University Press.

Czerny, Helga. 2005. Der Tod der bayerischen Herzöge im Spätmittelalter und in der frühen Neuzeit: 1347-1579. Vorbereitungen, Sterben, Trauerfeierlichkeiten, Grablegen, Memoria. Schriftenreihe zur Bayerischen Landesgeschichte 146. Munich: Beck.

Derschka, Harald. 2014. Individuum und Persönlichkeit im Hochmittelalter. Stuttgart: Kohlhammer.

Elm, Kaspar. 1992. 'Frömmigkeit und Ordensleben in deutschen Frauenklöstern des 13. und 14. Jahrhunderts', Ons geestelijk erf 66. 28-45.

Fuchs, Martin. 2015. 'Processes of Religious Individualization: Stocktaking and Issues for the Future', Religion 45.3. 330-43. 
Füser, Thomas. 2000. Mönche im Konflikt: zum Spannungsfeld von Norm, Devianz und Sanktion bei den Cisterziensern und Cluniazensern (12. bis frühes 14. Jahrhundert). Vita regularis 9. Münster: LIT.

Gillmann, Franz. 1924. 'Zu Gratians und der Glossatoren, insbesondere des Joh. Teutonicus Lehre über die Bedeutung der causa iusta für die Wirksamkeit der Exkommuniation', Archiv für Katholisches Kirchenrecht 104. 5-40.

Glaser, Hubert. 2002. 'Schwierige Erinnerung. Über das “Kaisergrab” in der Münchner Frauenkirche und andere Denkmäler Ludwigs des Bayern'. In Kaiser Ludwig der Bayer. Konflikte, Weichenstellungen und Wahrnehmung seiner Herrschaft. Quellen und Forschungen aus dem Gebiet der Geschichte NF 22, eds. Hermann Nehlsen and Hans-Georg Hermann, Paderborn: Schöningh. 1-37.

Goetz, Hans-Werner. 2016. Gott und die Welt, IV. Die Geschöpfe: Engel, Teufel, Menschen. Göttingen: V\&R unipress.

Hahn, Alois. 1997. 'Zur Soziologie der Beichte und anderer Formen institutionalisierter Bekenntnisse: Selbstthematisierung und Zivilisationsprozess'. In Soziologische Theorie und Empirie. Kölner Zeitschrift für Soziologie und Sozialpsychologie Jub.Bd., eds. Jürgen Friedrichs, Karl Ulrich Mayer and Wolfgang Schluchter, Opladen: Westdeutscher Verlag. 150-77.

Hahn, Alois. 2006. 'Theoretische Ansätze zu Inklusion und Exklusion'. In Cornelia Bohn (ed.). 67-88.

Hahn, Alois and Cornelia Bohn. 2002. 'Partizipative Identität, Selbstexklusion und Mönchtum'. In Das Eigene und das Ganze. Zum Individuellen im mittelalterlichen Religiosentum. Vita regularis 16, eds. Gert Melville and Markus Schürer, Münster. 3-25.

Hamm, Berndt. 2016. 'ludicium particulare. Personale Identität des Menschen und Gedächtnis Gottes in der spätmittelalterlichen Vorstellung vom Individualgericht'. In Geschichtsentwürfe und Identitätsbildung am Übergang zur Neuzeit, Band 1: Paradigmen personaler Identität. Abhandlungen der Akademie der Wissenschaften zu Göttingen NF 41.1, eds. Ludger Grenzmann, Burkhard Hasebrink and Frank Rexroth, Berlin: De Gruyter. 287-319.

Hammer, Andreas. 2015. Erzählen vom Heiligen: narrative Inszenierungsformen von Heiligkeit im Passional. Literatur - Theorie - Geschichte: Beiträge zu einer kulturwissenschaftlichen Mediävistik 10. Berlin: De Gruyter.

Helmholz, Richard H. 1982. 'Excommunication as a Legal Sanction: the Attitudes of the Medieval Canonists', Zeitschrift der Savigny-Stiftung für Rechtsgeschichte: Kanonistische Abteilung 68. 202-18.

Helmholz, Richard H. 1994. 'Excommunication in twelfth century England', Journal of Law and Religion 235. 235-53.

Herbert McAvoy, Liz (ed.). 2010. Anchoritic traditions of medieval Europe. Woodbridge, Suffolk: Boydell Press.

Hergenröther, Philipp. 1875. Die Appellationen nach dem Decretalenrechte. Eichstätt. Hirbodian, Sigrid. 2016. 'Die Dominikanerinnen - ein Überblick'. In Die deutschen Dominikaner und Dominikanerinnen im Mittelalter. Quellen und Forschungen zur Geschichte des Dominikanerordens NF 21, eds. Sabine von Heusinger et al., Berlin: De Gruyter. 21-36.

Huizing, Peter. 1955. 'The earliest development of excommunication latae sententiae by Gratian and the earliest decretists', Studia Gratiana 3. 277-320. 
logna-Prat, Dominique. 2005a. 'Édification personnelle et construction ecclésiale'. In L'individu au Moyen Âge: Individuation et individualisation avant la modernité, eds. Brigitte M. Bedos-Rezak and Dominique logna-Prat, Paris: Aubier. 247-70.

logna-Prat, Dominique. 2005b. 'Introduction générale: La question de l'individu à l'épreuve du Moyen Âge'. In L'individu au Moyen Âge: Individuation et individualisation avant la modernité, eds. Brigitte M. Bedos-Rezak and Dominique logna-Prat, Paris: Aubier. 7-32.

Irblich, Eva. 1988. 'Herrschaftsauffassung und persönliche Andacht Kaiser Friedrichs III., Maximilians I. und Karls V. im Spiegel ihrer Gebetbücher', 11-45.

Jaser, Christian. 2013. Ecclesia maledicens: rituelle und zeremonielle Exkommunikationsformen im Mittelalter. Spätmittelalter, Humanismus, Reformation 75. Tübingen: Mohr Siebeck.

Kaufhold, Martin. 1994. Gladius spiritualis: Das päpstliche Interdikt über Deutschland in der Regierungszeit Ludwigs des Bayern (1324-1347). Heidelberger Abhandlungen zur mittleren und neueren Geschichte NF 6. Heidelberg: Winter.

Kehnel, Annette. 2002. 'Gnadenlehre oder Reproduktionserfolg. Alte und neue, historische und biowissenschaftliche Geschichten zum Thema Individualität'. In Das Eigene und das Ganze. Zum Individuellen im mittelalterlichen Religiosentum. Vita regularis 16, eds. Gert Melville and Markus Schürer, Münster: LIT. 27-56.

Kober, Franz von. 1857. Der Kirchenbann nach den Grundsätzen des canonischen Rechts. Tübingen: Laupp.

Köbler, Gerhard. 2014. 'Appellation, Berufung, Schelte'. In Recht im Wandel - Wandel des Rechts: Festschrift für Jürgen Weitzel zum 70. Geburtstag, ed. Ignacio Czeguhn, Cologne: Böhlau. 281-302.

Kramer, Susan R. and Caroline W. Bynum. 2002. 'Revisiting the twelfth-century individual. The inner self and the christian community'. In Das Eigene und das Ganze. Zum Individuellen im mittelalterlichen Religiosentum. Vita regularis 16, eds. Gert Melville and Markus Schürer, Münster: LIT. 57-88.

Kruse, Britta-Juliane. 2012. 'Innere Einkehr, äußere Ordnung. Verhaltensregeln für Inklusen aus einem spätmittelalterlichen Rapiarium'. In Mertens lesen: exemplarische Lektüren für Volker Mertens zum 75. Geburtstag, eds. Monika Costard, Jacob Klingner and Carmen Stange, Göttingen: V\&R unipress. 67-88.

Lang, Bernhard. 2009. 'Persönliche Frömmigkeit: Ein Typus von Laienreligiosität in Geschichte und Gegenwart'. In Europäische Religionsgeschichte. Ein mehrfacher Pluralismus, eds. Hans G. Kippenberg, Jörg Rüpke and Kocku von Stuckrad, Göttingen: Vandenhoeck \& Ruprecht. 747-69.

Le Goff, Jacques. 1981. La naissance du Purgatoire. Paris: Gallimard.

Luhmann, Niklas. 1989. 'Individuum, Individualität, Individualismus'. In Gesellschaftsstruktur und Semantik. Studien zur Wissenssoziologie der modernen Gesellschaft 3, idem, Frankfurt am Main: Suhrkamp. 149-258.

Luhmann, Niklas. 1995. Soziologische Aufklärung, Bd. 6: Die Soziologie und der Mensch. Opladen: Westdeutscher Verlag.

Lusset, Élisabeth. 2011. 'Entre les murs. L'enfermement punitif des religieux criminels au sein du cloître (XII $-\mathrm{XV}^{\mathrm{e}}$ siècle)'. In Enfermements. Le cloître et la prison, $\mathrm{VI}^{\mathrm{e}}-\mathrm{XVIII}{ }^{\mathrm{e}}$ siècle: actes du colloque international organisé par le Centre d'études et de recherche en histoire culturelle. Série homme et société 38, eds. Isabelle Heullant-Donat, Julie Claustre and Élisabeth Lusset, Paris: Publications de la Sorbonne. 153-68.

Mansfield, Mary C. 1995. The humiliation of sinners: public penance in thirteenth-century France. Ithaca: Cornell University Press. 
Melville, Gert. 1996. 'Der Mönch als Rebell gegen gesatzte Ordnung und religiöse Tugend. Beobachtungen zu Quellen des 12. und 13. Jahrhunderts'. In De ordine vitae. Zu Normvorstellungen, Organisationsformen und Schriftgebrauch im mittelalterlichen Ordenswesen. Vita regularis 1, ed. idem, Münster: LIT. 153-86.

Melville, Gert. 2002. 'Einleitende Aspekte zur Aporie von Eigenem und Ganzem im mittelalterlichen Religiosentum'. Das Eigene und das Ganze. Zum Individuellen im mittelalterlichen Religiosentum. Vita regularis 16, eds. idem and Markus Schürer, Münster: LIT. XI-LXI.

Melville, Gert. 2005. 'Gehorsam und Ungehorsam als Verhaltensformen'. In Oboedientia. Zu Formen und Grenzen von Macht und Unterordnung im mittelalterlichen Religiosentum. Vita regularis. Abhandlungen 27, eds. Sébastien Barret and Gert Melville, Münster: LIT. 181-204.

Mensching, Günther. 1994. 'Kontemplation und Konstruktion. Zum Verhältnis von Mystik und Wissenschaft bei Hugo von St. Viktor'. In Scientia und ars im Hoch- und Spätmittelalter. Albert Zimmermann zum 65. Geburtstag 2. Miscellanea mediaevalia 22, eds. Ingrid Craemer-Ruegenberg and Andreas Speer, Berlin: De Gruyter. 589-604.

Mersch, Katharina U. 2013. 'Göttlich legitimierter Eigensinn. Gewissensfreiheit als Option im Umgang mit dem exkommunizierten Ludwig dem Bayern und dem Interdikt', Frühmittelalterliche Studien 47. 209-38.

Mersch, Katharina U. 2017. Missachtung, Anerkennung, Kreativität: Exkommunizierte Laien im 13. Jahrhundert. Unpublished manuscript (habilitation thesis, Göttingen).

Mersch, Katharina U. 2018. 'Überlegungen zum Verhältnis von Schuld, Reue und Intention am Beispiel der Ermordung des Erzbischofs Burchard III. von Magdeburg'. In Absichten, Pläne, Strategien. Erkundungen eines Problems der Vormoderneforschung. Kontingenzgeschichten 5, eds. Jan-Hendryk de Boer and Marcel Bubert, Frankfurt: Campus. 141-74.

Miethke, Jürgen. 1969. Ockhams Weg zur Sozialphilosophie. Berlin: De Gruyter.

Moos, Peter von. 2005. 'L'individu ou les limites de l'institution ecclésiale'. In L'individu au Moyen Âge: Individuation et individualisation avant la modernité, eds. Brigitte M. Bedos-Rezak and Dominique logna-Prat, Paris: Aubier. 271-88.

Moos, Peter von. 2006. 'Vom Inklusionsindividuum zum Exklusionsindividuum. Persönliche Identität in Mittelalter und Moderne'. In Cornelia Bohn (ed.). 253-65.

Münkler, Marina. 2009. 'Sündhaftigkeit als Generator von Individualität. Zu den Transformationen legendarischen Erzählens in der "Historia von D. Fausten" und den Faustbüchern des 16. und 17. Jahrhunderts'. In Literarische und religiöse Kommunikation in Mittelalter und Früher Neuzeit: DFG-Symposion 2006, ed. Peter Strohschneider, Berlin: De Gruyter. 25-61.

Musschenga, Albert W. 2001. 'Introduction: The many faces of individualism'. In The many faces of individualism. Morality and the meaning of life 12, eds. Anton van Harskamp and Albert W. Musschenga, Leuven: Peeters. 3-23.

Neumann, Friederike. 2008. Öffentliche Sünder in der Kirche des späten Mittelalters: Verfahren, Sanktionen, Rituale. Norm und Struktur: Studien zum sozialen Wandel in Mittelalter und früher Neuzeit 28. Cologne: Böhlau.

Oexle, Otto G. 2001. 'Konsens - Vertrag - Individuum. Über Formen des Vertragshandelns im Mittelalter'. In Das Individuum und die Seinen. Individualität in der okzidentalen und in der russischen Kultur in Mittelalter und früher Neuzeit. Veröffentlichungen des 
Max-Planck-Instituts für Geschichte 163, eds. Yuri L. Bessmertnyj and Otto Gerhard Oexle, Göttingen: Vandenhoeck \& Ruprecht. 15-38.

Otto, Bernd-Christian. 2017. 'Magic and religious individualization: On the construction and deconstruction of analytical categories in the Study of Religion', Historia Religionum 9. 29-52.

Reinhardt, Nicole. 2015. 'How individual was conscience in the early-modern period? Observations on the development of Catholic moral theology', Religion 45.3. 409-28.

Röckelein, Hedwig. 2014. 'Inklusion - Exklusion: weiblich - männlich'. In Innovationen durch Deuten und Gestalten: Klöster im Mittelalter zwischen Jenseits und Welt. Klöster als Innovationslabore. Studien und Texte 1, eds. Gert Melville et al., Regensburg: Schnell and Steiner. 127-44.

Rüpke, Jörg. 2013. 'Individualization and individuation as concepts for historical research'. In The individual in the religions of the Ancient Mediterranean, ed. idem, Oxford: Oxford University Press. 3-38.

Schmitt, Jean-Claude. 2001. 'La “découverte de l'individu”: une fiction historiographique?'. In Le corps, les rites, les rêves, le temps: essais d'anthropologie médiévale. Bibliothèque des histoires. idem, Paris: Gallimard. 241-62.

Schmolinsky, Sabine. 2012. Sich schreiben in der Welt des Mittelalters: Begriffe und Konturen einer mediävistischen Selbstzeugnisforschung. Selbstzeugnisse des Mittelalters und der beginnenden Neuzeit 4. Bochum: Winkler.

Signori, Gabriela. 2005. Räume, Gesten, Andachtsformen: Geschlecht, Konflikt und religiöse Kultur im europäischen Mittelalter. Ostfildern: Jan Thorbecke.

Simmel, Georg. 1968. Gesammelte Werke, Bd. 2. Soziologie: Untersuchungen über die Formen der Vergesellschaftung. Berlin: Duncker \& Humblot.

Stammberger, Ralf M. W. 2002. “Via ad ipsum sunt scientia, disciplina, bonitas”. Theorie und Praxis der Bildung in der Abtei St. Viktor im 12. Jahrhundert'. In 'Scientia' und 'Disciplina': Wissenstheorie und Wissenschaftspraxis im 12. und 13. Jahrhundert. Erudiri sapientia 3, eds. Rainer Berndt et al., Berlin: Akademie-Verlag. 91-126.

Struve, Tilman. 2006. Salierzeit im Wandel: zur Geschichte Heinrichs IV. und des Investiturstreites. Cologne: Böhlau.

Svec Goetschi, Milena. 2015. Klosterflucht und Bittgang: Apostasie und monastische Mobilität im 15. Jahrhundert. Zürcher Beiträge zur Geschichtswissenschaft 7. Cologne: Böhlau.

Swanson, Robert N. 2011. “In mortis articulo ...”: a fourteenth-century rite from Durham Cathedral priory to implement a papal plenary indulgence', Studia liturgica 41. 9-15.

Vodola, Elisabeth. 1986. Excommunication in the Middle Ages. Berkeley: University of California Press.

Vogel, Cyrille. 1975. 'Buße und Exkommunikation in der Alten Kirche und im Mittelalter. Ein historischer Überblick', Concilium 11. 446-52.

Wittneben, Eva L. 2003. Bonagratia von Bergamo: Franziskanerjurist und Wortführer seines Ordens im Streit mit Papst Johannes XXII. Studies in medieval and reformation thought 90. Leiden: Brill.

Wittneben, Eva L. 2004. 'Bonagratia von Bergamo († 1340): eine intellektuelle Biographie in der politischen Diskussion des 14. Jahrhunderts'. In Politische Reflexion in der Welt des späten Mittelalters: essays in honour of Jürgen Miethke. Studies in medieval and Reformation traditions 103, ed. Martin Kaufhold, Leiden: Brill. 247-67. 
